\title{
Morphometric sex determination from mastoid triangle in South Indian population
}

\author{
PK Singh ${ }^{1}$, RG Menezes ${ }^{2}$, BSK Shetty ${ }^{3}$, P Rastogi ${ }^{3}$, T Kanchan ${ }^{3}$, J Rao, P.P ${ }^{3}$, RB Y.P ${ }^{3}$ \\ Department of Forensic Medicine; Kathmandu University School of Medical Sciences, Dhulikhel, Nepal ${ }^{1}$, \\ Srinivas Institute of Medical Sciences \& Research Centre, Mangalore, India², \\ Kasturba Medical College, Mangalore, India ${ }^{3}$
}

\begin{abstract}
\section{Introduction}

The living has responsibility for the dead, particularly, in civilized societies which recognize the need for identity both in living and dead. Identity of a person means individuality of that person ${ }^{1}$. Identification is one of the main objectives of any medicolegal autopsy. Unknown bodies in full or in part and sometimes skeletal remnants are brought for examination. Identification is vital in such situations, and determination of sex, age, and stature can reduce the given population in smaller group.

being the second best region of skeleton to determine the gender, next to pelvis ${ }^{3,4}$. In the skull the mastoid region is favourable for sex determination, as it is the most protected region, due to its anatomical position at the base of the skull. Therefore this study has been undertaken to determine sex based on the triangular area calculated from the corresponding temporal bone obtained between the three easily identifiable carniometric landmarks i.e. the porion, mastoidale and asterion joining to form the mastoid triangle from both sides of the skull.
\end{abstract}

Forensic identification has evolved into an art of science which involves various specialties $^{2}$. Forensic anthropology is one such sub-specialty within Forensic Science, which deals with human skeletonised remains and their environment ${ }^{3}$. In the field of Forensic anthropology determining gender from skeletal remains, especially from isolated bones, has been an age old problem. In this context skull plays an important role,

\section{Address for correspondence}

Dr. Pankaj Kumar Singh

Department of Forensic Medicine

Kathmandu University School of Medical Sciences

Dhulikhel, Nepal

E-mail:drpankaj_s@yahoo.in

\section{Methods}

The present study was an autopsy based study of the mastoid triangle for sex determination of the skull. This study was conducted at the mortuary of the Government District Wenlock Hospital, Mangalore, South Canara, Karnataka, India. The study sample consisted of total 100 skull samples, 50 male and 50 female skulls autopsied at the centre mentioned above between June 2010 to July 2011. Cases with head injuries and fractures involving the mastoid triangle, temporal bone 
and base of the skull; partially fused ectocranial sutures surrounding the asterion; below 15 years of age (because the sutures at the asterion starts its fusion at this age) and above 60 years of age (asterion gets completely fused at this age); and partially or completely charred body were excluded from the study.

A coronal incision on skin was given from the tip of one mastoid process to the another running over the vertex. The scalp was retracted; the temporalis muscle and tendons of sternocleidomastoid muscle, trapezius muscle and splenius capitis muscle are separated with the help of scalpel and chiseled from the skull. Then the area corresponding to the mastoid triangle is scrapped off with sharp edge of chisel to clean the adherent pericranial tissue, then the area is cleaned with a clean piece of cloth and the three points are identified and marked.

The three points (Fig. 1) that are to be identified in this study are

1. Porion (Po) - the uppermost lateral point of the external auditory meatus ${ }^{5}$.

2. Mastoidale (Ms) - the lowest point of the mastoid process ${ }^{5}$.
3. Asterion (Ast) - the meeting point of the lambdoid, occipitomastoid, and parietomastoid sutures ${ }^{5}$.

The points are located and marked by a single investigator on both sides of the skull and sliding vernier calliper was used to measure the distance between these three points in centimetres. The area of the triangle was calculated using Heron's formula ${ }^{6}$.

The data were analyzed using Statistical Package for Social Sciences (SPSS) computer software assessing the correlation between the male and female the coefficient was calculated and its significance was tested by students "t" test. "P" value of less than 0.05 was considered as significant.

\section{Result}

The study comprised a total of 100 cadavers brought for medico legal autopsy at the centre mentioned above, of which 50 were male and 50 were female. The age distribution for males varies from 18 to 60 years with mean age 34.0 years, and for female the age varies from 18 to 56 years with mean age 31.58 years, as described in the table 1.

Table 1: Age of the sample study

\begin{tabular}{|l|l|l|l|l|}
\hline Sex & Minimum age & Maximum age & Mean & Standard deviation \\
\hline Male & 18 & 60 & 34.0000 & 10.54824 \\
\hline Female & 18 & 56 & 31.5800 & 11.11919 \\
\hline
\end{tabular}


The side wise analysis of mastoid triangles of right and left with each other for both the sex showed no significant difference in size. Whereas it was found that the different measurements showed very high significant difference for both the sexes, which are illustrated in the table 2 for right side and table 3 for left side, given below.

Table 2: Sex determination from right mastoid triangle

\begin{tabular}{|c|c|c|c|c|c|}
\hline Site & Side & $\mathbf{N}$ & Mean & $\begin{array}{l}\text { Standard } \\
\text { deviation }\end{array}$ & $\mathbf{T}$ \\
\hline \multirow[t]{2}{*}{ Asterion to porion (cm) } & Male & 50 & 4.5040 & 0.35339 & \multirow{2}{*}{$\begin{array}{l}4.18700 \\
p<0.001\end{array}$} \\
\hline & Female & 50 & 4.2400 & 0.27180 & \\
\hline \multirow[t]{2}{*}{ Asterion to mastoidale $(\mathrm{cm})$} & Male & 50 & 5.0880 & 0.33481 & \multirow{2}{*}{$\begin{array}{l}5.38700 \\
p<0.001\end{array}$} \\
\hline & Female & 50 & 4.6960 & 0.39069 & \\
\hline \multirow[t]{2}{*}{ Mastoidaleto porion (cm) } & Male & 50 & 3.1140 & 0.34107 & \multirow{2}{*}{$\begin{array}{l}4.32300 \\
p<0.001\end{array}$} \\
\hline & Female & 50 & 2.8140 & 0.35284 & \\
\hline \multirow[t]{2}{*}{ Area $\left(\mathrm{cm}^{2}\right)$} & Male & 50 & 6.8888 & 0.92969 & \multirow{2}{*}{$\begin{array}{l}5.82600 \\
p<0.001\end{array}$} \\
\hline & Female & 50 & 5.8380 & 0.87314 & \\
\hline
\end{tabular}

Table 3: Sex determination from left mastoid triangle

\begin{tabular}{|c|c|c|c|c|c|}
\hline Site & Side & $\mathbf{N}$ & Mean & $\begin{array}{l}\text { Standard } \\
\text { deviation }\end{array}$ & $\mathbf{T}$ \\
\hline \multirow[t]{2}{*}{ Asterion to porion (cm) } & Male & 50 & 4.5060 & 0.32097 & \multirow{2}{*}{$\begin{array}{l}4.26000 \\
p<0.001\end{array}$} \\
\hline & Female & 50 & 4.2600 & 0.25234 & \\
\hline \multirow[t]{2}{*}{ Asterion to mastoidale $(\mathrm{cm})$} & Male & 50 & 5.0980 & 0.31330 & \multirow{2}{*}{$\begin{array}{l}6.26400 \\
p<0.001\end{array}$} \\
\hline & Female & 50 & 4.6900 & 0.33761 & \\
\hline \multirow[t]{2}{*}{ Mastoidaleto porion (cm) } & Male & 50 & 3.1460 & 0.32212 & \multirow{2}{*}{$\begin{array}{l}5.10700 \\
p<0.001\end{array}$} \\
\hline & Female & 50 & 2.8200 & 0.31623 & \\
\hline \multirow[t]{2}{*}{ Area $\left(\mathrm{cm}^{2}\right)$} & Male & 50 & 6.9792 & 0.89628 & \multirow{2}{*}{$\begin{array}{l}6.55300 \\
p<0.001\end{array}$} \\
\hline & Female & 50 & 5.8762 & 0.78312 & \\
\hline
\end{tabular}

Since the two mastoid triangles of a skull showed no significantly different in size, the right and left sides were pooled together
$(\mathrm{N}=100)$ for both sexes. Then sex wise analysis which showed a significant difference as illustrated in the table 4. 
Table 4: Sex determination from the mastoid triangle when $(n=100)$

\begin{tabular}{|c|c|c|c|c|c|c|c|}
\hline Measurements & Sex & $\mathbf{N}$ & Min & Max & Mean & $\begin{array}{l}\text { Standard } \\
\text { deviation }\end{array}$ & $\mathbf{t}$ \\
\hline \multirow{2}{*}{$\begin{array}{l}\text { Asterion to Porion } \\
(\mathrm{cm})\end{array}$} & Male & 100 & 3.70 & 6.00 & 4.5050 & 0.33586 & \multirow{2}{*}{$\begin{array}{l}5.995 \\
p<0.001\end{array}$} \\
\hline & Female & 100 & 3.60 & 4.90 & 4.2500 & 0.26112 & \\
\hline \multirow{2}{*}{$\begin{array}{ll}\text { Asterion } & \text { to } \\
\text { Mastoidale }(\mathrm{cm}) & \end{array}$} & Male & 100 & 4.50 & 6.00 & 5.0930 & 0.32263 & \multirow{2}{*}{$\begin{array}{l}8.23 \\
p<0.001\end{array}$} \\
\hline & Female & 100 & 3.50 & 5.40 & 4.6930 & 0.36328 & \\
\hline \multirow{2}{*}{$\begin{array}{l}\text { Mastoidale } \\
\text { Porion }(\mathrm{cm})\end{array}$} & Male & 100 & 2.40 & 3.90 & 3.1300 & 0.33044 & \multirow{2}{*}{$\begin{array}{l}6.668 \\
p<0.001\end{array}$} \\
\hline & Female & 100 & 1.40 & 3.70 & 2.8170 & 0.33335 & \\
\hline \multirow[t]{2}{*}{ Area $\left(\mathrm{cm}^{2}\right)$} & Male & 100 & 5.40 & 9.67 & 6.9340 & 0.90965 & \multirow{2}{*}{$\begin{array}{l}8.767 \\
p<0.001\end{array}$} \\
\hline & Female & 100 & 2.98 & 8.04 & 5.8571 & 0.82538 & \\
\hline
\end{tabular}

In males, the length of Asterion to Porion varies from $3.70 \mathrm{~cm}$ to $6.00 \mathrm{~cm}$ with a mean 4.50, the length of Asterion to Mastoidale varies from $4.50 \mathrm{~cm}$ to $6.00 \mathrm{~cm}$ with a of mean 5.09, and the length of Mastoidale to Porion varies from $2.40 \mathrm{~cm}$ to $3.90 \mathrm{~cm}$ with a mean of 3.13.

In female, length of Asterion to Porion varies from $3.60 \mathrm{~cm}$ to $4.90 \mathrm{~cm}$ with a mean of 4.25 , the length of Asterion to Mastoidale varies from $4.50 \mathrm{~cm}$ to $6.00 \mathrm{~cm}$ with a mean of 4.69 , and the length of Mastoidale to Porion varies from $1.40 \mathrm{~cm}$ to $3.70 \mathrm{~cm}$ with a mean of 2.82 . Using the data, regression model equation was derived for sex determination for individual component of the mastoid triangle.
Regression model equation for estimation of sex from the length between Asterion to Porion:

$D=4.137-0.602 X$ Length between Asterion to Porion (cm)

In which:

\begin{tabular}{|l|l|l|l|}
\hline $\mathbf{R}$ & $\mathbf{R}^{2}$ & Standard error & $\mathbf{T}$ \\
\hline 0.392 & 0.154 & 0.462 & $\begin{array}{l}9.378 \\
\mathrm{p}<0.001\end{array}$ \\
\hline
\end{tabular}

The cut-off point to say the sex of the individual $=$ value less than 1.5 belongs to that of a male and value more than 1.5 belongs to that of a female.

The predicted analysis for sex in the sample collected: 


\begin{tabular}{|l|l|l|l|l|}
\hline & \multicolumn{1}{|c|}{$\begin{array}{c}\text { Male } \\
\text { sample }\end{array}$} & \multicolumn{1}{|c|}{$\begin{array}{c}\text { Female } \\
\text { sample }\end{array}$} & \multicolumn{1}{|c|}{ Total } \\
\hline Predicted as male & Count & 70 & 35 & 105 \\
\cline { 2 - 6 } & Percentage & $70.0 \%$ & $35.0 \%$ & $52.5 \%$ \\
\hline Predicted as female & Count & 30 & 65 & 95 \\
\cline { 2 - 5 } & Percentage & $30.0 \%$ & $65.0 \%$ & $47.5 \%$ \\
\hline
\end{tabular}

Regression model equation for estimation of sex from the length between Asterion to Mastoidale:

$D=4.620-0.638 \times$ Length between Asterion

The cut off point to say the sex of the to Mastoidale $(\mathrm{cm})$ individual $=$ value less 1.5 belongs to that of $\mathrm{a}$ In which:

\begin{tabular}{|l|l|l|l|}
\hline $\mathbf{R}$ & $\mathbf{R}^{2}$ & Standard error & $\mathbf{T}$ \\
of a female.
\end{tabular}

The predicted analysis for sex in the sample collected:

\begin{tabular}{|l|l|l|l|l|}
\hline & \multicolumn{1}{|c|}{$\begin{array}{c}\text { Male } \\
\text { sample }\end{array}$} & $\begin{array}{c}\text { Female } \\
\text { sample }\end{array}$ & \multicolumn{1}{|c|}{ Total } \\
\hline Predicted as male & Count & 73 & 34 & 107 \\
\cline { 2 - 6 } & Percentage & $73.0 \%$ & $34.0 \%$ & $53.5 \%$ \\
\hline Predicted as female & Count & 27 & 66 & 93 \\
\cline { 2 - 5 } & Percentage & $27.0 \%$ & $66.0 \%$ & $46.5 \%$ \\
\hline
\end{tabular}

Regression model equation for estimation of sex from the length between Mastoidale to Porion:

\begin{tabular}{|l|l|l|l|}
\hline 0.428 & 0.183 & 0.454 & $\begin{array}{l}12.317 \\
p<0.001\end{array}$ \\
\hline
\end{tabular}

$D=3.242-0.586 \times$ Length between The cut off point to say the sex of the Mastoidale to Porion (cm) In which:

\begin{tabular}{|l|l|l|l|}
\hline $\mathbf{R}$ & $\mathbf{R}^{2}$ & Standard error & $\mathbf{T}$ \\
\hline
\end{tabular}
individual $=$ value less than 1.5 belongs to that of a male and value more than 1.5 belongs to that of a female.

The predicted analysis for sex in the sample collected: 


\begin{tabular}{|l|l|l|l|l|}
\hline & & \multicolumn{1}{|c|}{ Male sample } & Female sample & \multicolumn{1}{|c|}{ Total } \\
\hline Predicted as male & Count & 67 & 34 & 101 \\
\cline { 2 - 5 } & Percentage & $67.0 \%$ & $34.0 \%$ & $50.5 \%$ \\
\hline Predicted as female & Count & 33 & 66 & 99 \\
\cline { 2 - 5 } & Percentage & $33.0 \%$ & $66.0 \%$ & $49.5 \%$ \\
\hline
\end{tabular}

Regression model equation for estimation of sex from the length between Areas:

$D=3.161-0.260 \times$ Area $\left(\mathrm{cm}^{2}\right)$

In which:

\begin{tabular}{|l|l|l|l|}
\hline $\mathbf{R}$ & $\mathbf{R}^{2}$ & Standard error & $\mathbf{T}$ \\
\hline 0.529 & 0.280 & 0.426 & $\begin{array}{l}16.478 \\
\end{array}$ \\
& & & $\mathrm{p}<0.001$ \\
\hline
\end{tabular}

The cut-off point to say the sex of the individual $=$ value less than 1.5 belongs to that of a male and value more than 1.5 belongs to that of a female.

The predicted analysis for sex in the sample collected:

\begin{tabular}{|l|l|l|l|l|}
\hline & & Male sample & Female sample & \multicolumn{1}{|c|}{ Total } \\
\hline Predicted as male & Count & 66 & 23 & 89 \\
\cline { 2 - 5 } & Percentage & $66.0 \%$ & $23.0 \%$ & $44.5 \%$ \\
\hline Predicted as female & Count & 34 & 77 & 111 \\
\cline { 2 - 5 } & Percentage & $34.0 \%$ & $77.0 \%$ & $55.5 \%$ \\
\hline
\end{tabular}

In mastoid triangle the length between asterion to mastoidale gives the best predicted value for sex determination $(r=$ $0.505)$ next to area of the mastoid triangle $(r$ $=0.529$ ). Therefore a combination of multiple measurements of the mastoid triangle is also formulated.

Regression model equation using multiple components of the mastoid triangle and the area of the mastoid triangle was derived.

$D=5.252-0.115 X$ Length between Asterion to Porion $(\mathrm{cm})-0.443 X$ Length between
Asterion to Mastoidale $(\mathrm{cm})-0.381 X$ Length between Mastoidale to Porion $(\mathrm{cm})+0.008 X$ Area $\left(\mathrm{cm}^{2}\right)$

In which:

\begin{tabular}{|l|l|l|}
\hline $\mathbf{R}$ & $\mathbf{R}^{2}$ & Standard error \\
\hline 0.563 & 0.317 & 0.418 \\
\hline
\end{tabular}

The cut off point to say the sex of the individual $=$ value less than 1.5 belongs to that of a male and value more than 1.5 belongs to that of a female. 
The predicted analysis for sex in the sample collected:

\begin{tabular}{|l|l|l|l|l|}
\hline \multirow{2}{*}{ Male } & & \multicolumn{1}{|c|}{ Male } & \multicolumn{1}{c|}{ Female } & \multicolumn{1}{c|}{ Total } \\
& Count & 71 & 27 & 94 \\
\cline { 2 - 5 } & Percentage & $71.0 \%$ & $27.0 \%$ & $49.0 \%$ \\
\hline \multirow{2}{*}{ Female } & Count & 29 & 73 & 106 \\
\cline { 2 - 5 } & Percentage & $29.0 \%$ & $73.0 \%$ & $51.0 \%$ \\
\hline
\end{tabular}

When all the components of mastoid triangle are combined and a formula is derived the predictability increased $(r=0.563)$. Therefore it is advisable to combine all the parameters instead of taking individual parameters. However the percentage of overlapping in between male and female is $52.5 \%$.

\section{Discussion}

Identification is the basis of individuality of a person. Skeleton is the part of the body that resists all environmental insults for maximum time, and can help to determine the sex, estimate the age, race and stature of the person. Determination of sex is one important parameter. It has already been shown that people in different regions, different races and ethnic groups vary considerably in proportion of their respective skeletal frame. For identification one requires standard criteria which are specifically based to the group to which the person belongs. Due to lack of study in reference to sex determination from the mastoid triangle in this part of the World underlines the importance of the present study. In the skull the mastoid region is favourable for sex determination, as it is the most protected region and resistant to damage, due to anatomical position at the base of the skull ${ }^{5}$.

The different measurement of the mastoid triangle i.e. Asterion to Porion, Asterion to Mastoidale, Mastoidale to Porion, and the area of the mastoid triangle, is taken from both sides of the skull. When the sidewise analysis was done for both the sex for each measurement, it was found that there is no significant difference ( $p=$ more than 0.622$)$. But when sex-wise analysis was done the accuracy of determining sex from our study is found to be higher for all the parameters of the mastoid triangle, indicated by the highly significant $p$ value $(p<0.001)$, which is in accordance with the study conducted by Paiva $^{5}$, Segre ${ }^{5}$ in 2003, but his study was conducted on the Xerox copy of the mastoid triangle in dry skull. 
In another study conducted by Galdames $\mathrm{ICS}^{7}$, Matamala $\mathrm{DAZ}^{7}$ and Smith $\mathrm{RL}^{7}$, a similar result was seen in the Brazilian population, where in the mastoid triangle measurements were taken directly on the dry skull and was found to be sexually dimorphic. This study is superior to the study conducted by Paiva ${ }^{4}$ and Segre $^{4}$ as this study in conducted on the dry skull.

The study conducted by Kemkes $A^{6}$ and Gobel $^{6}$, in two different populations, one being German and another Portuguese population, concluded that the mastoid triangle is a population specific and that the Portuguese sample is more sexually dimorphic than the German population.

A study conducted in North India by Singh $\mathrm{RP}^{8}$, Verma $\mathrm{SK}^{8}$, and Tyagi $A K^{8 \mathrm{~s}}$, come to a similar conclusion that Mastoid triangle was sexually dimorphic in North Indians. The study restricted itself to individual measurement and the area calculated in various age groups for male and female.

In the present study, we established that the Mastoid triangle is sexually dimorphic, the sides do not pose any difference in the determination in sex. The regression equations which were formulated can further help the Forensic experts to determine the sex with much ease. In relation to regression equation, area of the mastoid triangle showed high accuracy $(52.9 \%)$, but when all the measurements were taken into account and regression equation is formulated, the accuracy was very significantly raised (56.3\%). The percentage of overlapping $(52.5 \%)$ in our study is also less as compared to the previous study $(60 \%)$.

\section{Conclusion}

In conclusion, the results of the study indicate that the area of the mastoid triangle could be used to determine the gender in case of fragmentary remains of the skull. However the other measurements can be taken in account but are not a good indicator for sex determination when used individually. However, there is scope for further study with a larger sample size to emphasize the above findings and to arrive at accurate demarcating points.

\section{References}

1. Mukherjee JB. Personal Identification. In: Forensic Medicine and toxicology. $2^{\text {nd }} \mathrm{ed}$. New Delhi: Arnold Associates, 1994:72, 128-129.

2. Knight B. Identification. The establishment of identity of human remains. In: Knight's Forensic Pathology. $3^{\text {rd }}$ ed. London: Arnold, 2004: 98-135.

3. Krogman WM, Iscan MY. In Skeletal Age: Cranium, Skeletal Age: Post Cranium and Determination of Sex and Parturition. In: The human skeleton in Forensic Medicine. $2^{\text {nd }}$ ed. USA: Charles C 
Thomas Publishers, 1986: 103-267, 153187.

4. Luiz AS and Marco S. Sexing the human skull through the Mastoid process. Rev. hos. Clin. Fac. Med. S. Paulo 2003; 58(1): 15-20.

5. Paiva LAS and Serge M. Sexing the human skull through the mastoid process. Rev Hosp Clin Fac Med 2003; 21: 15-20.

6. Kemkes A and Gobel T. Metric Assessment of the Mastoid Triangle for Sex Determination: A Validation Study. J
Forensic Sci September 2006; 51: 985989.

7. Galdames ICS, Matamala DAZ and Smith RL. Sex determination Using Mastoid Process in Brazilian Skull. Int J. Morphol 2008; 26(4): 941-944.

8. Singh RP, Verma SK, and Tyagi AK. Determination of sex by measurement of the area of mastoid triangle in human skull. Indian Internet Journal of Forensic Medicine \& Toxicology 2008; 6(2): ISSN 0973-1970. 